References

Berthelsen, A. and Noe-Nygaard, A. (1965) The Precambrian of Greenland. In Rankama, K. (edit.) The Precambrian, Vol. 2, 113-262. London and New York: Interscience Publ.

Jepsen, H. F. (1967) Intrusive rocks of the Midsommers $\phi$ area, southern Peary Land and their stratigraphical position. Rapp. Grønlands geol. Unders., Nr. 11, 8-10.

Koch, L. (1929) Stratigraphy of Greenland. Meddr Grønland, Bd. 73, Afd. 2, Nr. 2.

Troelsen, J.C. (1949) Contributions to the geology of the area round Jørgen Brønlunds Fjord, Peary Land, North Greenland. Meddr Grønland, Bd. 149, Nr. 2.

Troelsen, J.C. (1956) The Cambrian of North Greenland and Ellesmere Island. 20 Congr. geol. intern. Mexico, 1956, Symp. 3, t. 1, $71-90$.

\title{
NEW MAPPING AND SPECIAL RESEARCH ON
} NÛGSSUAQ AND DISKO

\section{A. Rosenkrantz}

In order to supplement the results of previous expeditions to the Cretaceous-Tertiary areas of West Greenland the Survey, with financial support from the Carlsberg Foundation, sent a group to northern Disko, Hare $\varnothing$, and western Nûgssuaq which was the main area for the group's activities. The expedition was supported by the 26 ton motor cutter "J. F. Johnstrup", and two jeeps for transport in the open valleys.

The new mapping concerned mainly an area in Nugssuaq between $52^{\circ} 30^{\prime}$ and $52^{\circ} 40^{\prime} \mathrm{W}$. This mapping was necessary because the eastern boundary of the 1:100000 sheet "Agatdal" was moved eastwards to 
$52^{\circ} 30^{\prime} \mathrm{W}$ to allow the part of West Greenland between $70^{\circ} 30^{\prime}$ and $71^{\circ} 00^{\prime} \mathrm{N}$ to be covered in two sheets. In addition revision was carried out on the Qutdligssat and Agatdal sheets which in earlier years had been mapped on an inadequate topographic base. Furthermore the presence of the thick basalt formations with associated magnetic disturbance made the measurement of strike and of the many tectonic elements very difficult. For a long time it had been hoped that eventually with the help of aerial photographs it would be possible to make up for these shortcomings. In the course of the last year the necessary photogeological interpretation was carried out by G. Henderson who during the summer checked his impression of certain areas by investigations of many localities spread over the whole district (see p. 18).

A special study of the plateau basalts - particularly the iron basalts was carried out in northern Disko and Hare $\varnothing$ by A. Ken Pedersen (see p. 21).

As long ago as during the Danish Nugssuaq expeditions of 1938 and 1939 ("De danske Nûgssuaq ekspeditioner 1938 og 1939", financed by the Carlsberg Foundation and "Grønlands Styrelse" and also under the leadership of the writer) observations were made which gave grounds for the conjecture that on Nugssuaq, Disko and Svartenhuk there were possibilities for oil reserves. This was based on the presence of at least $1000 \mathrm{~m}$ thickness of bituminous shales from the Senonian and Danian which at several places along the coast of Nugssuaq where there had been landslides were burning or previously had burnt. Furthermore the occurrence of natural gas was discovered; the excape of gas is the main reason for the development of mud volcanoes (pingoes) found in the big valleys of Nagssuaq, Disko and Svartenhuk and is confined to areas underlain by bituminous or coal-bearing sediments. In recent years several oil companies have shown an interest in these gas and bituminous shale occurrences. On G. Henderson's initiative, therefore, shale samples for oil source rock analysis were collected from 22 localities on Nûgssuaq and one on Disko. The samples were collected in as fresh a state as possible, in some cases with the help of explosives. The samples are now being analysed. As soon as the results are available it is intended to publish a paper on the oil and gas prespects in this area at an early date.

At the same time as collecting the bituminous shales for oil source rock analysis $\mathrm{H}$. J. Hansen investigated the marine shales for foraminifera. 
These could in a few cases be found enclosed in calcareous concretions in the shales, where their identification involves great difficulties. Investigations of the shales using new methods has so far given negative results, probably because the foraminifera shells originally present were dissolved and their calcite content taken up in concretions. In the Upper Danian of Agatdal the foraminifera are found in the sandstone and especially in finegrained sediment enclosed in gastropod shells. H. J. Hansen, who is working on this fauna, in addition carried out a special investigation of the character of the Danian sediments in order to elucidate the environment in which the foraminifera lived.

K. Binzer undertook a detailed sedimentological investigation of the thick conglomerate at the base of the Danian around Angnertuneq on Nûgssuaq's north coast and the coarse conglomerates of the Upper Danian in Agatdal. Textures and current directions were clarified, and a big collection was made of the boulders which are mainly of gneiss.

At Marrait kitdlit, $4 \mathrm{~km}$ NW of the party's base at Marrait kangigdlit, a thorough investigation was made of a tuff series in which in $1964 \mathrm{~K}$. Binzer found a marine fossiliferous unit which also filled in vertical fissures in the tuff beds. The series is overlain by pillow lavas. During this investigation it was confirmed that the very pale, almost white, calcareous sediment contains pillows and volcanic bombs, which undoubtedly killed off the marine animals in the sea. The fossil finds comprise foraminifera, bryozoa, several species of gastropods, and lamellibranchs (especially oysters). In 1968 we were successful in finding several spines of a Tylocidaris which is identical to forms found in the Upper Danian of Agatdal. The age of the sediments at Marrait kitdlit is therefore undoubtedly Upper Danian; the occurrence is interesting because it is far from the earlier known localities of the same age in Agatdal.

The tuffs immediately above the marine horizon at Marrait kitdlit are cut by fissures filled with the rare mineral xonotlite and are undoubtedly the site of H. Rink's old finds from 1852. A large number of samples of xonotlite were taken.

In addition to the activities already described a big collection of Senonian-Danian fossils was made in Agatdal, especially from the OysterAmmonite Conglomerate which has been known for many years. The 
collecting was carried out mainly by L. Simonarson and the Greenlanders Abraham L $\phi$ vstr $\phi m$, Andreas Tobiassen, Sachemann M $\phi 1 l e r$ and Nikolaj Tobiassen. The Greenlanders have all assisted expeditions led by the writer over many years - the two first-named since 1938 - and are excellent collectors. The Senonian ammonites, nautiloids, decapods, lamellibranchs, gastropods and brachiopods are found here in concretions which during the transgression of the Danian sea were eroded out of the youngest Senonian (Maastrichtian) beds. In central Nugssuaq the Maastrichtian sediments had been completely removed by the beginning of the Danian. The fossil material is in an exceptionally good state of preservation which allows a detailed electron microscope study of the embryonic and later stages of shell growth, particularly in ammonites and other cephalopods. The summer's collecting brought forward several species hitherto unknown from Greenland.

In 1964 a lot of shells were collected in marine Quaternary deposits at Pátorfik on the north coast of Nûgssuaq. $\mathrm{C}^{14}$ dating of the shells by $\mathrm{H}$. Tauber showed that the deposits must be interglacial, more than 35000 years old. This meant that a strip of marine deposits along a long stretch of coast east of Qaersut must be interglacial. Because much of this coastal stretch now comes within the Agatdal sheet as a result of this sheet's boundaries having been shifted eastwards, L. Simonarson in 1968 undertook an investigation of these deposits. Detailed profiles were measured in the sediments, which are strongly deformed as a result of the last glaciation. Samples for sedimentological, pollen and foraminifera studies, and a large amount of shells were collected. 